\section{(6) OPEN ACCESS}

\title{
Can tobacco control endgame analysis learn anything from the US experience with illegal drugs?
}

\author{
Peter Reuter
}

\section{Correspondence to}

Professor Peter Reuter, Senior Economist RAND Corporation, Research Fellow, IZA, School of Public Policy and Department of Criminology, University of Maryland

4103 Van Munching Hall, College Park, MD 20742, USA preuter@umd.edu

Received 28 September 2012 Revised 1 January 2013 Accepted 8 January 2013
To cite: Reuter P. Tob Control 2013;22:i49-i51.

\section{ABSTRACT}

The goals of tobacco control endgame strategies are specified in terms of the desired levels of tobacco use and/or tobacco related health consequences. Yet the strategies being considered may have other consequences beyond tobacco use prevalence, forms and related harms. Most of the proposed strategies threaten to create large black markets with potential attendant harms: corruption, high illegal earnings, violence and/or organised crime. Western societies of course have considerable experience with these problems in the context of prohibition of drugs such as cannabis, cocaine, heroin and methamphetamine. These experiences suggest that low prevalence has been achieved only by tough enforcement with damaging unintended consequences. Tobacco prohibition (total or partial) may not present the same trade-off but there is little basis for making a projection of the scale, form and harms of the attendant black markets. Nonetheless, these harms should not be ignored in analyses of the endgame proposals.

Cigarette black markets are commonplace in high tax jurisdictions. For example, estimates are that contraband cigarettes now account for $20-30 \%$ of the Canadian market, ${ }^{1}$ which has restrained government enthusiasm for raising taxes further. All the proposed 'endgame' proposals for shrinking cigarette prevalence toward zero run the risk of creating black markets. This is generally recognised in the literature but in a dismissive tone, as just another mildly troubling detail. Typical is Thomson et $a l^{2}$ who note that among possible adverse effects of a 'sinking lid' (fixed and declining quantity of tobacco available for legal distribution) is that '(h)igh priced tobacco could result in the following adverse consequences: smuggling at sufficient levels to erode the price signal (eg, if border controls are inadequate); increased theft from wholesalers, retailers and smokers (and some illegal sales); and illegal cultivation for commercial sales'. Black markets are seen only as a threat to accomplishing the endpoint, not as constituting a distinct problem in themselves. Not another word is said about these effects. In doing so, the authors follow current practice in the public health community. For example, the recent analysis by the Tobacco Product Safety Advisory Council (TPSAC) ${ }^{3}$ of the consequences of banning mentholated cigarettes acknowledged that the TPSAC could say little about the scale and kinds of black markets but made no mention of any other consequences that would flow from the markets other than a weakening of the prohibition.
Perhaps these new black markets will turn out to be just another minor detail but the experience with prohibition of cocaine, heroin, marijuana and methamphetamine shows that this is not guaranteed. For all of these drugs except marijuana the prevalence of regular use is extremely low, perhaps less than $2 \%$. Unfortunately, the prohibitionist policies that have achieved these low rates impose large costs on both users and the general community. For marijuana the social costs of the lightly enforced prohibition observed over the last four decades have been modest but the prevalence of regular use among the population over 15 years of age has been high; most adolescents experiment with the drug and the prevalence of regular use might be as high as $10 \% .{ }^{4}$ The purpose of this article is to suggest, on the basis of the US experience with illegal drugs, what factors might lead to large black markets in cigarettes and emphasize the need for analysis of endpoints beyond prevalence in assessing the various proposals.

\section{THE BLACK MARKETS FROM THE ENDGAME PROPOSALS}

Whether it is a sinking fund, ${ }^{2}$ prohibition for birth cohorts after a certain date ${ }^{5}$ or simple prohibition, ${ }^{6}{ }^{7}$ the proposals create incentives to supply cigarette-like products to those who either face an extremely high legal price for that product or who are entirely cut off from legal purchase. Even the proposal for reducing the nicotine content of legally marketed tobacco products poses that same risk $;{ }^{8}$ the currently preferred product would not be legally available.

The size (number of users, quantity consumed or revenues) of the black market for each proposal is impossible to predict even roughly. Partly it depends on the dynamics of the specific proposal. Tom Schelling (personal communication) has speculated that since most smokers want to quit, a sudden ban might lead to massive cessation in the period before the black market made access easy again; the would-be quitters could welcome the chance to follow-through on their ambition. That reasoning suggests that the black market would be larger if the restrictions tightened gradually, as for example with the sinking lid or the post-2000 birth cohort ban, which would generate slowly increasing incentives for black market provisions. Jonathan Caulkins (personal communication), on the other hand, stresses that black markets work poorly when demand is small; the birth cohort proposal might work well precisely because the black market for 15 -year olds in 2015 would be small, so that with an inefficient market, few of them might start smoking. 
The nature of the black market product is also difficult to predict. In general black markets produce more readily concealed and more dangerous forms of what is prohibited; when opiates are banned, opium users are likely to switch to the more efficient and easily concealed heroin. Cigarettes are hard to consume inconspicuously. Would the black market generate a different high-nicotine product that makes consumption less conspicuous and would that be more or less harmful to the health of the consumer?

The harms from the black markets also depend on the price of a black-market cigarette habit. If a black-market pack cost $\$ 10$, a figure already reached in New York City through a combination of federal state and local taxes, then a pack-a-day habit costs about $\$ 3500$ per annum, compared with the roughly $\$ 12000$ cost of a cocaine habit in $2006 .^{9}$ The crime consequences would be low at the $\$ 10$ per pack level; what if the cost of maintaining the habit reached $\$ 12000$ per annum?

That leads to the question of what will determine the price of a black-market pack. The strictness of enforcement is theoretically an important factor but there is precious little evidence from illegal drug markets that tough punishments and aggressive policing raises prices much beyond what is achieved through prohibition and a modest level of enforcement. ${ }^{10}$

\section{THE COSTS ARISING FROM BLACK MARKETS IN DRUGS}

A series of estimates of the economic costs of illegal drugs find that the principal cost is generated not by consumption and its direct health consequences but by the crime and criminal justice costs. ${ }^{11} 12$ The latest figure, for 2002, is \$193 billion. Some of these crime costs are the result of the psychoactive properties of the drugs themselves; cocaine and methamphetamine reduce inhibitions and facilitate aggression, referred to as psychopharmacological effects. The few efforts to partition drug related crime among the psychopharmacological effects, the crimes that result from 'economic compulsive' motives (ie, the need to raise funds for expensive drugs) and systemic violence (committed by sellers in the course of their business), have found that the psychopharmacological effects account for a small share. ${ }^{13-15}$ Thus one cannot dismiss the relevance of black market experiences with these drugs just because cigarettes have mild psychoactive effects.

Cocaine, heroin and methamphetamine are the three expensive illicit drugs of importance in the USA. For none of these drugs do more than two per cent of the adult population use on a monthly basis and the total for the three drugs, taking into account polydrug use, is probably about three per cent. ${ }^{9}$ Yet the conditions created in order to obtain that low prevalence are such as to lead to calls for radical changes, perhaps even legalisation, from many quarters, including recently a high level panel including some distinguished former Latin American presidents. ${ }^{16}$ The costs include some that are not relevant to tobacco control, such as overdoses (from purity and tolerance uncertainty) and bloodborne viruses, generated by conditions of use for injecting drug users. However the most costly problems relate to the black market: violence among dealers; the disorder surrounding local markets in many cities; the attraction of low income young males into drug selling and dropping out from school; the incarceration of such large numbers of African-American males; the corruption and violence in countries such as Colombia and Mexico. Perhaps it was necessary and appropriate to vigorously attack drug production and distribution but the case for doing so has to take into account these salient and important unintended consequences.
Marijuana appears to provide the closest parallel to the potential black market for cigarettes. It is a very lightly processed, naturally occurring weed, readily grown in many countries and ecological settings. Use of the substance is a normal activity in adolescence in most western countries. ${ }^{17}$ Though it has much more substantial psychoactive effects than tobacco, no matter how the latter is manipulated, the effects are much less severe than those of cocaine, heroin or methamphetamine.

The social costs associated with marijuana markets are modest, notwithstanding an estimated $\$ 20$ billion revenue in $2008 .^{18}$ Within the USA, marijuana distribution, and even cultivation, is associated with low levels of violence. ${ }^{17}$ Corruption allegations are also rare. On the other hand, in Mexico both the production and distribution of marijuana contributes to the pervasive and extraordinary drug-related corruption and violence. ${ }^{19}$

Marijuana enforcement generates a large number of arrests for simple possession, ca 800000 annually, about half of all drug arrests. Very few result in any incarceration ${ }^{20}$ but arrest and conviction itself can have harmful effects in the form of loss of employment and housing opportunities. ${ }^{21}$ Marijuana enforcement attracts vigorous criticism, and not just because the drug is easy to purchase and of low price, measured in terms of the cost per hour of intoxication. Racial disparities are troubling: in 2008 black users were about three times more likely than whites to be arrested. In 2012 the New York City Police Department was credibly accused of using marijuana possession arrests as an inappropriate way of controlling minority populations. $^{21} 22$ Pretrial detention is a common consequence, even if there is no sentence of incarceration following conviction. ${ }^{23}$

\section{CONCLUSION}

Endgame proposals involve tightening legal access to cigarettes; they are all likely to create black markets. These markets are a policy threat not simply because they will raise prevalence of cigarette smoking but because of the potential violence, corruption, crime and enforcement costs (both monetary and humanitarian) that they may engender. The critique of prohibition of cocaine, heroin and methamphetamine is less about the numbers who continue to use these drugs than the other costs associated with the regime. The critique of marijuana prohibition on the other hand is that it may have shifted those costs to other countries, mostly Mexico, as well as failed to make marijuana use a rare behaviour. It appears that the choice is between tough enforcement that suppresses use but generates many harms or accepting high rates of prevalence of illegal consumption and keeping those other harms low. There is no lack of plausible and clever proposals for better prohibition strategies (eg, ref. ${ }^{24}$ ) but these seem to face systematic political barriers for implementation.

The endgame proposals differ in important ways from the prohibition of the psychoactive drugs. No proposal includes prohibition on consumption or possession of a banned product or by an unauthorised person. However, the history of prohibition suggests caution; these are not static phenomena. If the proposal is unsuccessful (however judged) in its milder form, the political temptation to make it more comprehensive, in this case by criminalising unauthorised possession, may be difficult to resist. After all, these proposals are not merely technocratic measures but the very stuff of mass politics, creating new constituencies and interests.

It is impossible at present to predict the consequences of the black markets that might arise from the various proposals. The black markets may be modest and manageable by sensible public policy; they may be large and systemically difficult to deal with. The control policies to deal with these markets may be sensible and fair; they may turn out to be oppressive and corrupt. 
This phenomenon requires a kind of modelling that has not yet been attempted and which will present a serious intellectual challenge if the proposals are taken seriously. The black markets can be technologically dynamic. For example, these proposals aim at specific forms of nicotine delivery. In face of that, it is possible that other forms of legal nicotine delivery will be developed that will mitigate the black market demand. The modelling may be difficult but, at a minimum, discussion of these proposals should include such endpoints as the cost of enforcement, the increase in numbers incarcerated and the extent of illegal revenues. Even intelligent guesses at these would help anchor the analyses in reality.

\section{Key Messages}

- All endgame proposals offer incentives for black markets in cigarette-like products.

- Black markets have the potential to create harms, such as violence, corruption and illegal incomes, in addition to increasing tobacco use and related health effects.

- The experience with marijuana and other illicit drugs suggests that these market-related harms can be very substantial.

- Though there is no systematic way of projecting how large these markets and related harms will be, it is important to acknowledge their existence and potential for reducing social wellbeing.

\section{Competing interests None.}

Provenance and peer review Not commissioned; externally peer reviewed.

Open Access This is an Open Access article distributed in accordance with the Creative Commons Attribution Non Commercial (CC BY-NC 3.0) license, which permits others to distribute, remix, adapt, build upon this work non-commercially, and license their derivative works on different terms, provided the original work is properly cited and the use is non-commercial. See: http://creativecommons.org/ licenses/by-nc/3.0/

\section{REFERENCES}

1 Royal Canadian Mounted Police. Contraband tobacco enforcement strategy. Ottawa, Ontario: Customs \& Excise Branch, Border Integrity, Federal \& International Operations, 2008

2 Thomson G, Wilson N, Blakely T, et al. Ending appreciable tobacco use in a nation: using a sinking lid on supply. Tob Control 2010;19:431-5.
3 Tobacco Product Scientific Advisory Council. Menthol cigarettes and public health: review of the scientific evidence and recommendations. Washington, DC: Food and Drug Administration, 2011.

4 Substance Abuse and Mental Health Services Administration. National survey on drug use \& health. Rockville, MD: SAMHSA, annual.

5 Khoo D, Chiam Y, Ng P, et al. Phasing-out tobacco: proposal to deny access to tobacco for those born from 2000. Tob Control 2010;19:355-60.

6 Daynard RA. Doing the unthinkable (and saving millions of lives). Tob Control 2009;18:2-3.

7 Proctor RN. Golden holocaust: origins of the cigarette catastrophe and the case for abolition. 1st edn. Berkeley: University of California Press, 2012

8 Benowitz NL, Henningfield JE. Establishing a nicotine threshold for addiction. The implications for tobacco regulation. N Engl J Med 1994;331:123-5.

9 Rhodes W. What America's users spend on illicit drugs, 1988-2006. Washington, DC: Executive Office of the President, 2012.

10 Caulkins J, Reuter P. How drug enforcement affects drug prices. Crime and Justice: A Rev Res 2010;39:213-71.

11 Harwood H, Fountain D, Livermore G. The economic costs of alcohol and drug abuse in the United States, 1992. Washington, DC: U.S. Department of Health and Human Services, 1998.

12 Office of National Drug Control Policy. The economic costs of drug abuse in the United States, 1992-2002. c2004 [cited 24 May 2012]; Publication No. 207303. https://www.ncjrs.gov/ondcppubs/publications/pdf/economic_costs.pdf (accessed 23 Jan 2013).

13 Goldstein PJ. The drugs/violence nexus: a tripartite conceptual framework. J Drug Issues 1985;15:493-506.

14 Goldstein PJ, Brownstein HH, Ryan PJ. Drug-related homicide in New York: 1984 and 1988. Crime Delinquency 1992;38:459-76.

15 Goldstein PJ, Brownstein HH, Ryan PJ, et al. Crack and homicide in New York City, 1988: a conceptually based event analysis. Contemp Drug Probl 1989;16:651-87.

16 Global Commission on Drugs. War on drugs: report of the Global Commission on Drug Policy. C2011. [cited 21 Aug 2012]. http://www.globalcommissionondrugs. org/wp-content/themes/gcdp_v1/pdf/Global_Commission_Report_English.pdf (accessed 26 Jan 2013).

17 Room R, Fischer B, Hall W, et al. Cannabis policy: moving beyond stalemate. Oxford: Oxford University Press, 2010.

18 Kilmer B, Caulkins J, Pacula R, et al. Bringing perspective to illicit markets: estimating the size of the US marijuana market. Drug Alcohol Depend 2011;119:153-60.

19 Kilmer B, Caulkins JP, Bond B, et al. Reducing drug trafficking revenues and violence in Mexico: would legalizing marijuana in California help? Santa Monica, CA: RAND, 2010

20 Caulkins JP, Sevigny E. How many people does the US incarcerate for drug use, and who are they? Contemp Drug Probl 2005;32:405-28.

21 Gelman A, Fagan J, Kiss A. An analysis of the New York City police department's "stop-and-frisk" policy in the context of claims of racial bias. J Am Stat Assoc 2007; 102:813-23.

22 Geller A, Fagan J. Pot as pretext: marijuana, race, and the new disorder in New York City street policing. J Empirical Legal Studies 2010;7:591-633.

23 Reuter P, Hirschfield P, Davies K. Assessing the crackdown on marijuana in Maryland. University of Maryland, 2001 (Unpublished). http://www.drugpolicy.org/ docUploads/md_mj_crackdown.pdf (accessed 26 Jan 2013)..

24 Kleiman MAR. When brute force fails: how to have less crime and less punishment. Princeton: Princeton University Press, 2010. 